\title{
Interpretacje
}

\section{Ekstatyczne eksplozje. Wajda, afekty i reparacja}

Sebastian Jagielski

TEKSTY DRUGIE 2018, NR 1, S. 343-357

DOI: $10.18318 /$ td.2018.1.19

K ino Andrzeja Wajdy zawsze - a przynajmniej w okresie jego największej świetności ${ }^{1}$ - było sztuką zmysłową. Reżyser przedkładał spektakl nad narrację, a emocjonalną energię nad intelektualne rozważania. W uniwersum tym szczególnie brzemienne w znaczenia okazują się obrazy lotne i migawkowe, ale nieodmiennie intensywne i gwałtowne, które na ogół nie są zakorzenione w tkance fabularnej i mogą wydawać się - z punktu widzenia ekonomii narracji - zbędne. $W$ teorii filmu konwencja ta została ujęta $\mathrm{w}$ kategorię destrukcyjnego „ekscesu” - znaku nadwyżki, czyli wszystkiego tego, co przekracza potrzeby narracji filmowej ${ }^{2}$. Mamy z nim do

1 Przedmiotem swojego zainteresowania uczynię te filmy Wajdy, które zostały zrealizowane między 1954 a 1982 rokiem, czyli między debiutanckim Pokoleniem a zamykającym złoty okres w jego twórczości Dantonem. Później kino to utraci swój niezwykły impet, chociaż nigdy właściwie nie utraci rangi.

2 Pojęcie to definiuję za: K. Thompson The Concept of Cinematic Excess, w: Narrative, Apparatus, Ideology, ed. by P. Rosen, Columbia University Press, New York 1986, s. 130-142.
Sebastian Jagielski

- dr, adiunkt w Katedrze Historii Filmu

Polskiego Instytutu Sztuk Audiowizualnych UJ. Autor monografii Maskarady męskości. Pragnienie homospołeczne w polskim kinie fabularnym (2013), współredaktor tomu Ciało i seksualność w kinie polskim (2009). Publikował m.in. W ${ }_{\text {"Studies in }}$ Eastern European Cinema” i „Kwartalniku Filmowym". Kontakt: sebastian.jagielski@ uj.edu.pl 
czynienia wtedy, gdy niektóre sceny, ujęcia, bohaterowie, obiekty i akcesoria, a także niekonwencjonalna praca kamery, ekstrawagancka mise-en-scène czy rzucające się w oczy style w niewielkim tylko stopniu, jeśli w ogóle, wiążą się $\mathrm{z}$ diegetycznym jądrem filmu. Słynna spektakularna scena erotyczna w salonce z Ziemi obiecanej (1974), w której cechująca się pierwotnym, niepohamowanym i destrukcyjnym pragnieniem Lucy Zackerowa (Kalina Jędrusik) zachłannie pożera palcami mięso i spazmatycznie wgryza się w uwolnione ciało Karola Borowieckiego (Daniel Olbrychski), to czysty przykład ekscesu (dlatego z taką łatwością przyszło reżyserowi w 2000 roku wykastrować ten fragment z nowej, przemontowanej wersji filmu).

Pojęcie „ekscesu” odsyła do „trzeciego sensu” z artykułu Rolanda Barthes'a, w którym autor przedmiotem swego zainteresowania uczynił kilka fotogramów z Iwana Groźnego (1944) Siergieja Eisensteina. Trzeci sens to jego zdaniem "pewne zgęszczenie szminki u dworzan" - niczym ostentacyjnie sztuczny uśmiech, maska radości wymalowana na trupiobladej twarzy-płótnie Stasia z Brzeziny (1970) Wajdy - czyli to, co nadmierne i dodatkowe, ale też nieuchwytne, płynne, otwarte, choć uparte. Punktem wyjścia zarówno dla Barthes'a, jak i dla teoretyków ekscesu było przeświadczenie, że filmowy tekst nie sprowadza się do tego, co oczywiste, nie wyczerpuje się w tym, co na powierzchni. Heterogeniczność utworu ujawnia się wtedy, gdy dominujące reprezentacje, struktury narracyjne i formalne ulegają destabilizacji, umożliwiając tym samym „eksplozję" nienormatywnych - np. cielesnych czy politycznych - znaczeń. Kluczowe okazują się tu punkty zakłócające narrację, świadczące o tym, że kontrola nad znaczeniem w nią wpisanym wydaje się słabnąć. Dla Rolanda Barthes'a trzeci sens oznaczał „kontropowiadanie”:

rozproszony, odwracalny, przywiązany do własnego trwania może zaofiarować (jeśli się za nim pójdzie) tylko pewien odmienny rodzaj rozcięcia. Jest to rozcięcie planów, sekwencji i syntagm (technicznych lub narracyjnych), rozcięcie nieoczekiwane, przeciwlogiczne i jednocześnie "prawdziwe". ${ }^{4}$

$\mathrm{Na}$ owych „nieoczekiwanych rozcięciach”, przemieszczeniach i nieciągłościach ufundowane jest kino Wajdy, kino oparte na zakłóceniach, odchyleniach i lukach, które okazują się bardziej ważkie i doniosłe niż precyzja

3 R. Barthes Trzeci sens, przeł. R. Wyborski, "Kino” 1971 nr 11, s. 37.

4 Tamże, s. 40. 
narracji przyczynowo-skutkowej. W legendarnej scenie tańca na bankiecie we Wszystko na sprzedaż (1968) Elżbieta Czyżewska zagryza dolną wargę i trwa w samotnym zapamiętaniu, a kamera rejestruje zawistne spojrzenia, miny i grymasy salonu. Ten nonkonformistyczny performans, będący aktem oporu, nieposłuszeństwa i niesubordynacji, odsyła do rzeczywistego ostracyzmu, z jakim spotkała się aktorka w czasie poprzedzającym wydarzenia marcowe. Scena, w której gwiazda - korzystając z ochrony, jaką daje filmowa fikcja "odgrywa" siebie i demonstruje niezgodę na akceptację narzuconej jej pozycji podległości („zdrajczyni polskości”), jest owym Barthes'owskim rozcięciem, tekstualną szczeliną, jest - ekscesem ${ }^{5}$.

Co intrygujące, $w$ Wajdowskim nadmiarze, w marginalnych dla głównego nurtu akcji (choć w istocie mitycznych i legendarnych) punktach tekstowych pęknięć, idzie tyleż o formę, co o afekty, o mające nas, widzów, poruszyć stężenia i przyspieszenia. Afekt $u$ Wajdy jest transmitowany za sprawą gwałtownego, spontanicznego ruchu ciała, który pobudza inne ciała na ekranie i poza nim - jak histeryczny i ekspresyjny Cybulski w Popiele i diamencie (1958), tańczący wokół Olbrychskiego Wojciech Pszoniak w Ziemi obiecanej czy transgresyjna, głodna prawdy Krystyna Janda w Człowieku z marmuru (1976), ale to nie wszystko, bowiem afekt - oprócz ciała - przekazywany jest tu także, a może przede wszystkim, poprzez formę (pracę kamery, mise-en-scène czy montaż). Owe opozycyjne, jak się zdaje, kategorie - formy i afektu - zestawia ze sobą Eugenie Brinkema w książce The Forms of the Affects, argumentując, że zwrot afektywny w humanistyce nie wymazał problemu formy, reprezentacji i strategii close reading, wręcz przeciwnie - ,afekt wcale nie jest tam, gdzie czytanie nie jest już konieczne"6. Afekt - czyli to, co ulotne i intensywne, będące rezultatem pobudzenia, działania i wzajemnego afektowania się ciał ${ }^{7}$ nie jest odporny na czytanie. Więcej nawet, tylko za sprawą formy, zdaniem amerykańskiej filmoznawczyni, „należy czytać"8 $\mathrm{i}$ analizować

5 Szerzej piszę o tym gdzie indziej: S. Jagielski „Niech mnie wszyscy kochaja”. Transnarodowe ciało Elżbiety Czyżewskiej, w: Kino polskie jako kino transnarodowe, red. S. Jagielski, M. Podsiadło, Universitas, Kraków 2017, s. 157-178. .

6 E. Brinkema The Forms of the Affects, Duke University Press, Durham-London 2014, s. xiv.

7 Por. G.J. Seigworth, M. Gregg An Inventory of Shimmers, w: The Affect Theory Reader, ed. by M. Gregg, G. J. Seigworth, Duke University Press, Durham-London 2010, s. 1-25. Por. też: K. Bojarska Poczuć myślenie: afektywne procedury historii i krytyki (dziś), "Teksty Drugie” 2013 nr 6, s. 8-16.

8 E. Brinkema The Forms of the Affects, s. 19. 
struktury afektywne. Badania nad afektami nazbyt gorliwie koncentrowały się dotąd (na Zachodzie, dodajmy) na niekontrolowanych reakcjach widzów czy nieuchwytnych natężeniach i drżeniach. Oczywiście strategia ta odegrała doniosłą rolę: ujęcie afektu jako siły amorficznej, przedwerbalnej i przedspołecznej ${ }^{9}$ pozwoliło zmierzyć się z dominacją paradygmatu reprezentacjonistycznego, umożliwiło odzyskanie ignorowanego przez hegemoniczną teorię filmu zmysłowego wymiaru kina oraz somatycznej i haptycznej recepcji10. Brinkemie nie idzie zatem o zanegowanie owego afektywnego paradygmatu skupionego na tym, co ekspresyjne i wewnętrzne, odrzucenie poszukiwań efemerycznych punktów zakłócających narracje, reprezentacje i konwencje czy wreszcie o opór wobec zgłębiania - jak choćby w klasycznym tekście Lindy Williams - cielesnych reakcji widzów (łez, potu czy erekcji) na niektóre gatunki filmowe (melodramat, horror, pornografię) ${ }^{11}$, lecz o rozszerzenie i uzupełnienie tych poszukiwań o bliską i wnikliwą analizę afektywnych struktur formalnych. Autorka wyróżnia dwie strategie: „czytanie ze względu na formę" i „czytanie afektów jako posiadających formy”. Pierwsza wrażliwa jest na wymazaną z badań nad afektami tekstualność (w centrum sytuowano zwykle widza, a nie tekst), druga z kolei polega na „postrzeganiu afektów jako struktur, które działają za sprawą środków formalnych" (linii, światła, barwy, rytmu etc.) $)^{12}$.

Tym samym wyświetlenie - na podstawie kilku krótkich scen z wczesnego okresu twórczości Wajdy - afektywnych struktur tworzących styl jego filmów oraz próba scharakteryzowania - przy wykorzystaniu narzędzi

9 Afekty ujmuje się zwykle jako to, co poza językiem, poza świadomą wiedzą, co z kolei przywodzi na myśl - znowu - pojęcie „trzeciego sensu” Barthes'a: „zdaje się on [trzeci sens - przyp. S.J.] rozwijać poza kulturą, wiedzą i informacją" (tegoż Trzeci sens, s. 38). Swoją drogą, przekraczający "psychologię i anegdotę, funkcję i [...] konkretne znaczenie" (tamże) trzeci sens dał impuls do rozwijania teoretycznej refleksji nie tylko nad filmowym ekscesem, lecz także właśnie nad afektami. Antycypował zresztą też późniejsze prace Barthes’a z Przyjemnością tekstu iŚwiatłem obrazu na czele.

10 Por. np. S. Shaviro The Cinematic Body, University of Minnesota Press, Minneapolis-London 1993; L.U. Marks The Skin of the Film: Intercultural Cinema, Embodiment, and the Senses, Duke University Press, Durham-London 2000; tejże Touch. Sensuous Theory and Multisensory Media, University of Minnesota Press, Minneapolis-London 2002; J.M. Barker The Tactile Eye:Touch and the Cinematic Experience, University of California Press, Berkeley-Los Angeles-London 2009.

11 L. Williams Film Bodies: Gender, Genre, Excess, w: Film and Theory: An Anthology, ed. by R. Stam,

T. Miller, Blackwell, Malden 2000, s. 207-221. 
wypracowanych na gruncie psychoanalizy - rodowodu owego ufundowanego na ekscesie języka filmowego pozwala na powrót do afektywnej przeszłości, zespolenie nowego sposobu rozumienia kina $\mathrm{z}$ afektywnym dziedzictwem, i równocześnie na przypomnienie, że problematyka ta ma w teorii i historii kina długą i niebagatelną tradycję ${ }^{13}$.

\section{Patos i orgazm}

Styl filmów Andrzeja Wajdy krytycy usiłowali rozszyfrować, odwołując się zwykle albo do polskiego malarstwa, albo sztuki i kina zachodnioeuropejskiego - np. Pokolenie wiązano z neorealizmem, Kanat (1956) z ekspresjonizmem, Popiót $i$ diament $\mathrm{z}$ barokiem, Lotna (1959) z surrealizmem, a Niewinnych czarodziejów (1960) i Wszystko na sprzedaż z francuską Nową Falą. Struktura formalna i afektywna siła klasycznych scen z filmów Wajdy odsyłają nas także, co być może zaskakujące, do teorii i kina Siergieja Eisensteina. Krytycy rzadko kojarzyli styl polskiego reżysera z twórczością Eisensteina, co nie znaczy, że tropy te w dyskursie krytycznym w ogóle się nie pojawiały. W czasie premiery Popiołu i diamentu można było natrafić na opinie, że film ten jest „polskim Pancernikiem Potiomkinem"14, a niedawno Krzysztof Kornacki w książce poświęconej temu utworowi zauważył, że „silnie patronuje [mu - przyp. S.J.] radzieckie kino montażowe (osiągnięcia Kuleszowa, Eisensteina i Pudowkina), tyle że częściowo ukryte pod maską Wellesowskiej koncepcji głębinowej inscenizacji"15. Co istotne, w 1952 roku, na samym początku drogi twórczej, ukazał się na łamach „Kwartalnika Filmowego” artykuł Konrada Nałęckiego i Andrzeja Wajdy Kompozycja obrazu w filmach dźwiękowych Eisensteina ${ }^{16}$. Tekst

13 Whistorii teorii filmu cezura przed i po zwrocie afektywnym, jak przekonująco dowodzi Brinkema, trudna jest do wyznaczenia. Zanim pojawiła się w latach 9o. XX wieku afektywna teoria filmu, badacze kina i sami twórcy wielokrotnie podejmowali kwestie emocji, uczuć, trzewi i ekstazy (Hugo Münsterberg, Jean Epstein, Siegfried Kracauer czy wreszcie Siergiej Eisenstein). Ale oczywiście dopiero lata 9o. rozpoczynają "długie dekady afektu" (E. Brinkema The Forms of the Affects, s. 26) w refleksji o kinie: od prac inspirowanych Deleuzjańską lekturą Spinozy, przez zainteresowanie kognitywistów emocjami, po fenomenologiczne, feministyczne i queerowe rozważania skoncentrowane na ciele (także ciele filmu), dotyku, skórze i haptyczności (tamże, s. 27-28).

14 J. Falkowski Polonez tragiczny, „Współczesność" 1958 nr 27. K. Kornacki Popiółi diament Andrzeja Wajdy, słowo/obraz terytoria, Gdańsk 2011, s. 282.

16 „Wajda zabiegał później, żeby uznano mu go za pracę magisterską, ale szkoła nie wyraziła na to zgody" (T. Lubelski Wajda, Wydawnictwo Dolnośląskie, Wrocław 2006, s. 59). 
ten koncentruje się na kompozycji plastycznej: malarstwie bizantyjskim i gotyckim w Aleksandrze Newskim (1938) oraz barokowym w Iwanie Groźnym ${ }^{17}$, ale tym, co łączy Eisensteina i Wajdę, wcale nie są inspiracje malarskie, lecz sposób postrzegania formy i afektów/emocji. Radzieckiemu reżyserowi szło przede wszystkim o „filmową retorykę afektów, która [...] ma wywoływać $\mathrm{w}$ widzu określone stany afektywne"18. Słowa te korespondują z rozpoznaniem samego Wajdy, który pod koniec lat 50. zauważył: „wartości emocjonalne cenię najbardziej. Filmy intelektualne nie trafiają do widza[,] są w gruncie rzeczy bezwartościowe. Jest to przede wszystkim sprawa formy [...]. Środki muszą być emocjonalne - by oddziaływać, bohaterowie - by wzruszać"19. Tym samym zarówno u Wajdy, jak i u Eisensteina emocje (czy raczej: afekty ${ }^{20}$ ) postrzegane są jako struktury, które oddziałują na widza za sprawą formy. Inaczej: forma ( $u$ Eisensteina głównie montaż, u Wajdy - inscenizacja ${ }^{21}$ ) nie

Autorzy pomijają drugą część Iwana Groźnego - Spisek bojarów (1945) - zauważając, że "autorska koncepcja postaci Iwana, jako człowieka o szczególnie skomplikowanej, chorobliwej psychice [...], doprowadziła do [...] zupełnego załamania osiągnięć artystycznych" (K. Nałęcki, A. Wajda Kompozycja obrazu w filmach dźwiękowych Eisensteina („Aleksander Newski $i_{\text {"Iwan }}$ Groźny" cz. I) , "Kwartalnik Filmowy" 1952 nr 8, s. 26). Na potwierdzenie swej oceny Nałęcki i Wajda przywołują Uchwałę KC WKP(b) krytykującą Eisensteina za to, że "człowieka o silnej woli i charakterze uczynił istotą chwiejną, pozbawioną woli, jakimś Hamletem" (tamże). Swoją drogą, psychologia II części Iwana Groźnego rzeczywiście mogła Wajdę irytować, jego twórczość jest bowiem - jak polski romantyzm, z którego kino to wyrasta - zasadniczo antypsychologiczna. Inna sprawa, że w tekście nie brakuje życzliwych słów pod adresem realizmu socjalistycznego i złośliwości wobec zachodniego kina i zachodnich teoretyków filmu, co dowodzi, że negatywna ocena Spisku bojarów mogła być uwarunkowana politycznie.

S. Sasse Patos i antypatos. Formuły patosu u Siergieja Eisensteina i Aby'ego Warburga, przeł. P. Piszczatowski, „Widok. Teorie i praktyki kultury wizualnej” $2014 \mathrm{nr} 6$, http://widok.ibl.waw.pl/ index.php/one/article/view/213/356/ (1.06.2016).

B. Mruklik Andrzej Wajda, Wydawnictwa Artystyczne i Filmowe, Warszawa 1969, s. 35.

Nie utożsamiam pojęcia „afekt" z terminem „emocje”, bliska jest mi jednak kategoria "kondycji afektywnej" (afficere - wywoływać zmiany, wpływać) „obejmującej wszystkie niewolicjonalne i nieintelektualne reakcje na to, co wydarza się w świecie: emocje, odczucia, uczucia, nastroje, namiętności, pragnienia. [...] Oczywiście granice między poszczególnymi sektorami kondycji afektywnej [...] są płynne, podobnie jak nieostre są granice między kondycją afektywną i nieafektywną" (M.P. Markowski Emocje. Hasło encyklopedyczne w trzech częściach i dwudziestu trzech rozdziałach (nie liczq̨c motta), w: Pamięć i afekty, red. Z. Budrewicz, R. Sendyka, R. Nycz, Wydawnictwo IBL PAN, Warszawa 2014, s. 350-351). stein Autoportret, przeł. T. Szczepański, w: Eisenstein - artysta myśliciel, Wydawnictwa Artystyczne i Filmowe, Warszawa 1982, s. 11). 
ma na celu naśladowania czy reprodukowania rzeczywistości, lecz wytwarzanie emocji. Kwestie te najtrafniej ujmuje, zdaniem reżysera Pancernika Potiomkina (1925), pojęcie "patosu” czy „ekstazy” (terminami tymi posługuje się on wymiennie).

Eisensteinowski patos nie ma wszelako nic wspólnego ze „starym patosem" pojmowanym jako wyrażający się w gestach i mimice patos teatralny (reżyser ilustruje go sceną przepełnionej lamentem procesji błagalnej ze Starego i nowego, 1929). „Nowy patos” tworzony jest za sprawą „,kompozycyjnych środków wyrazu, a nie - aktorskiej egzaltacji bohaterów" ${ }^{22}$, to patos „ukinowiony", a nie czysto przedstawieniowy, patos formy, a nie treści. Więcej nawet, patetyczny temat - jak np. w przypadku Pancernika Potiomkina - przeszkadza zdaniem radzieckiego reżysera w odkrywaniu „ekstatycznej struktury”, gdyż ją przesłania. Czym jest zatem „ukinowiony” patos? Ów „nowy patos” to "ciągły stan uniesienia, nieustanne «wychodzenie z siebie», permanentne przechodzenie każdego poszczególnego elementu lub rysu utworu z jakości w jakość" 23 . Proces przechodzenia z jednego stanu emocjonalnego w drugi prowadzi do spiętrzenia napięcia i raptownego rozładowania, co Eisenstein ilustruje niepozorną, jak mogłoby się zdawać, sceną z centryfugą w Starym i nowym, którą zamykają erotyzowane „fajerwerki mleka”. Z opartym na narastaniu napięcia i nagłym rozładowaniu patetycznym efektem mamy także do czynienia we wczesnych filmach Wajdy, zwłaszcza w spektakularnych, widowiskowych sekwencjach cierpienia i śmierci.

Jak w scenie zabicia Szczuki (Wacław Zastrzeżyński) przez Maćka (Zbigniew Cybulski) z Popiołu i diamentu, którą sam Wajda uważa za „znaczeniowy kod DNA całego filmu"24. Szczuka opuszcza hotel, a Maciek podąża za nim, po czym chodzi - wyraźnie zdenerwowany i niezdecydowany - tam i z powrotem. Następnie wyprzedza mężczyznę, idzie wzdłuż płotów, odwraca się i strzela do swej ofiary, która pada w jego ramiona. Szczuka kona w objęciach innego mężczyzny, a scena ta trwa dłużej niż wymagałyby tego względy filmowej narracji. Niepokojącą pauzę przerywa w końcu gwałtowny i nieoczekiwany wybuch sztucznych ogni, pełniących funkcję Eisensteinowskiego wyładowania. Krzysztof Kornacki zauważa, że bardzo szybkie

S. Eisenstein Patos, w: tegoż Nieobojętna przyroda, przeł. M. Kumorek, Wydawnictwa Artystyczne i Filmowe, Warszawa 1975, s. 56.

23

24

Tamże, s. 51.

K. Kornacki Popiół i diament..., s. 238. Skądinąd to dosyć nieoczekiwane wyznanie, moglibyśmy się bowiem spodziewać, że reżyserowi bliższa jest słynna scena ze "spirytusowymi zniczami". 
i nierytmiczne tempo wprowadza w tej scenie „odbiorczy dyskomfort”. Wajda wcześniejsze długie ujęcia (montaż wewnątrzujęciowy i mobilna kamera) zestawia tu z - jak ujmuje to autor - „króciutkimi montażowymi «wybuchami»" (jedno z ujęć ma długość 0,15 metra, czyli trwa 0,3 sekundy). Kornacki zapytuje następnie: „Może o taką nerwowość, «histeryczność» montażu twórcom chodziło? Ale w takim razie kolejne ujęcie w planie ogólnym oczekiwanie Cybulskiego i Zastrzeżyńskiego w jego ramionach na wizualną puentę, czyli wystrzały rac - ciągnie się zbyt długo”25. Owo zderzenie „histerycznego" montażu z wyczekiwaniem na widowiskowy finał kojarzy się z Eisensteinowską „figurą narastania” i „ekstatyczną eksplozją"26. Jak w orgiastycznej i erotycznej scenie z centryfugą ze Starego i nowego: z jednej strony długie i niepokojące oczekiwanie, z drugiej zaś raptowne i niespodziewane wyładowanie.

Dominique Fernandez, analizując patos w Pancerniku Potiomkinie kluczem psychoanalitycznym, zapytuje: „czy istnieje jakiekolwiek inne przeżycie, które bardziej nieuchronnie zmusza człowieka do przejścia z jednego stanu w drugi, do wyjścia z siebie, aby przeskoczyć w przeciwną jakość, aniżeli przeżycie erotyczne?"27. Eisenstein, który - począwszy od lektury w wieku dwudziestu lat Leonarda da Vinci wspomnień z dzieciństwa Freuda, pracy, w której odnalazł, jak sam przyznał, „wspomnienia z własnego dzieciństwa” - był pod ogromnym wpływem psychoanalizy (warto dodać, że w latach 20. freudyzm cieszył się dużym powodzeniem w ZSRR $)^{\mathbf{2 8}}$, w liście do Wilhelma Reicha z początku lat 30., prosząc o jego książkę o orgazmie, zauważa, że „sztuka ma wiele wspólnego z centralnym problemem istoty żyjącej, z orgazmem" ${ }^{\text {"29 }}$. Chociaż Wajda, jak sam mówił, o Freudzie dowiedział się „za późno, żeby móc to spożytkować jako własną siłę"30 to w swoich wczesnych filmach usiłował stworzyć terapeutyczny język psychoseksualny, mający podobny do freudowskiego

Tamże, s. 241.

S. Eisenstein Patos, w: tegoż, Nieobojętna przyroda, s. 186.

D. Fernandez Eisenstein: drzewo i korzenie, przeł. M. Szczepańska, „Film na Świecie” 1991 nr 1, s. 76. Por. też: A. Britton Sexuality and Power, or the Two Others, w: Britton on film. The Complete Film Criticism of Andrew Britton, ed. by B. Keith Grant, Wayne State University Press, Detroit 2009, s. 287-311.

T. Szczepański Eisenstein i psychoanaliza, "Kino” 1979 nr 11, s. 27-28.

Korespondencję Siergieja Eisensteina i Wilhelma Reicha opracował i przełożył Tadeusz Szczepański, „Kino” 1979 nr 11, s. 28.

A. Wajda Nowy film..., rozm. B. Michałek, "Kino” 1968 nr 1, s. 42. 
status ${ }^{31}$. Tym samym zarówno Eisenstein, jak i Wajda obrazy, które mają wyrazić gwałtowne, sprzeczne i nieprzystające do siebie afekty: zazdrość i pożądanie, miłość i nienawiść, jouissance i rozpacz, opierają na formule „ekstatycznej eksplozji", która przywodzi na myśl orgazm.

Rozważaniami Eisensteina podszyty jest nie tylko Wajdowski „efekt ekstazy", lecz także obsesyjne powracanie i odtwarzanie sytuacji szokowych (II wojna światowa czy śmierć bliskich: ojca, Andrzeja Wróblewskiego czy Zbigniewa Cybulskiego). Formuła patosu - wiążąca się z nanizywaniem następujących po sobie elementów, które wyłaniają się z innych lub przechodzą w inne, prowadząc do ekstatycznego wyładowania - ma także swój rewers czy, jak ujmuje to Eisenstein, „pasywną stronę”. Rozdzielenie formy i treści oraz połączenie ich w sposób „nienaturalny”, zaskakujący i niestosowny wywołuje efekt szoku. „A sam «szok» - pisał radziecki reżyser - jest jak gdyby odbitym w krzywym zwierciadle skokiem w nową jakość, kiedy w pewnej chwili «rozpada się domek z kart» i przewraca ustalony «porządek rzeczy», ład, który wydawał się być niewzruszony i odwieczny" ${ }^{\text {"32 }}$.Te filmy Wajdy, które zostały oparte na metodzie swobodnego nanizywania kontrastujących ze sobą obrazów, a zwłaszcza obiektów w żaden sposób ze sobą niekorespondujących, niepowiązanych tematycznie ani niewynikających z siebie nawzajem, ukazują świat po katastrofie, gdy dawny ład został obrócony wniwecz. Odwrócony krzyż w kaplicy podczas rozmowy kochanków, nieumotywowane pojawienie się białego konia i śmierć Maćka na śmietniku (Popiót i diament); pokruszone antyczne posągi i stukający kopytami koń w magnackim pałacu, łapiące oddech, zdychające w kuchni ryby (nawiązujące - dodajmy - do przepołowionych ryb z obrazu Wróblewskiego), które później - antycypując los ułanów - zostaną zjedzone przez kota, wreszcie welon panny młodej zahaczony o trumnę i trumna wypełniona jabłkami (Lotna). Struktura wczesnych filmów Wajdy opiera się na Eisensteinowskim antypatosie, destabilizującym filmową narrację i wzbudzającym zarazem niepokój.

Nie dziwi więc, że Lotna czy Popioły (1965) okazały się dla wielu widzów wstrząsem, krytycy z kolei pisali o prowokacji, nie tylko ze względu na krytyczny wobec narodowej przeszłości potencjał owych filmów, ale także atakujące zmysły widzów zagęszczenia, napięcia, konflikty i kontrasty. Recenzenci

31 Por. Ch. Caes Widowiska katastroficzne: trauma historyczna i męska podmiotowość we wczesnych filmach Andrzeja Wajdy, przeł. Ch. Caes, Z. Batko, w: Filmowy świat Andrzeja Wajdy, red. E. Nurczyńska-Fidelska, P. Sitarski, Universitas, Kraków 2003, s. 141-178. 
oczekiwali tradycyjnej, wiernej historycznej rekonstrukcji, natomiast Wajda kładł nacisk na emocjonalny skrót. U Wajdy, jak pisała Elżbieta Ostrowska, „estetyczny nadmiar obrazu i dźwięku sprawia, że funkcja przedstawiania ustępuje funkcji wyrażania”, same sceny natomiast często „nie prezentują określonej sytuacji historycznej", lecz są ,jej afektywną metaforą" ${ }^{\text {"3 }}$. Słowem, "metafory emocjonalnych stanów" zamiast wiernej rekonstrukcji, co okazuje się tym bardziej znaczące, że emocje postrzegano tradycyjnie jako sprzeczne z obiektywnymi i racjonalnymi badaniami historycznymi. Ujęcie Historii w afektywne ramy przyczyniło się do początkowego odrzucenia Kanału, Lotnej, Popiołów czy Samsona (1961), po premierze którego pisano, że „okupacja była inna" i że w warszawskim salonie z pewnością nie było fontanny. Po latach amerykański slawista, Christopher Caes, odpowiadając na druzgocącą krytykę Lotnej pióra Alicji Helman - która oczekiwała "artystycznej transpozycji” i „syntezy rzeczywistości”, a otrzymała „pseudo-apokaliptyczną wizję o charakterze maniakalno-obsesyjnym"34 - zauważył: „zamiast ogłaszać film klęską artystyczną, czy nie lepiej byłoby przetworzyć własne wartościowanie, aby nie odrzucać, ale próbować dojść celu takiej estetyki?"35.

\section{Od kina traumy do kina nadziei?}

Genezy afektywnych struktur Wajdowskiego języka filmowego, stylistycznego ekscesu, szokujących połączeń, nanizywania kontrastujących ze sobą elementów i inscenizowania scen-orgazmów szukać powinniśmy w traumie - wojennej, historycznej i prywatnej. Jak pisała Eve Kosofsky Sedgwick, "pragnienie przyrostu i nawarstwienia" wiąże się z impulsem reparacyjnym ${ }^{36}$. Oparty na „przyroście” i „nawarstwieniu” eksces - niczym kamp z tekstu amerykańskiej badaczki - pełni u Wajdy funkcję terapeutyczną. Połączenie dwóch rozbieżnych modeli freudowskich: „modelu traumy kastracyjnej” (symbolizacja) i „modelu neurozy traumatycznej” (opóźnienie), pozwala

E. Ostrowska "Katyń" Andrzeja Wajdy: melodramatyczny afekt i historia, "Pleograf” 2016 nr 1, http://akademiapolskiegofilmu.pl/pl/historia-polskiego-filmu/pleograf/andrzej-wajda/1/ katyn-andrzeja-wajdy-melodramatyczny-afekt-i-historia/536 (1.06.2016).

A. Helman Sarmata na płonq̨cejżyrafie, „Ekran” 1959 nr 42, s. 3.

Ch. Caes Widowiska katastroficzne..., s. 163. myślisz, że ten tekst jest o tobie, przeł. M. Szcześniak, „Widok. Teorie i praktyki kultury wizualnej” 2014 nr 5, s. 30, http://widok.ibl.waw.pl/index.php/one/article/view/184/299/ (1.06.2016). 
zdaniem Paula Coatesa pojąć współwystępowanie w filmach Wajdy m.in.: szoku wojennego, surrealizmu, praktyk adaptacji literackiej (ekranizowanie utworów starszych od reżysera mężczyzn - zastępczych ojców) i deklarowanego braku satysfakcji z własnych dzieł ${ }^{37}$.Za sprawą ponownego przeżywania, odtwarzania i powtarzania szoku dokonywała się w sali kinowej kolektywna żałoba. Poprzez wstrząs i "prowokację" - fabularną (Kanał, Lotna, Popioły), ale przede wszystkim stylistyczną (Popiót i diament, Lotna, Wszystko na sprzedaż) wczesne kino Wajdy negocjowało i przepracowywało katastrofy i traumy. Te zbiorowe, ale i jednostkowe - traumy i kryzysy samego reżysera.

W psychoanalizie pokonywanie pozycji depresyjnej czy żałoby odbywa się za pomocą odtworzenia utraconego obiektu. Zdaniem Melanie Klein jednostka "poprzez pracę żałoby odtwarza nie tylko ten, ale też wszystkie swoje kochane wewnętrzne obiekty, które [...] utraciła" ${ }^{38}$. W ślad za utratą idzie reparacja ${ }^{39}$ : „[u]możliwia ona zwrócenie się ku własnym zasobom w celu złożenia na nowo lub «naprawy» morderczych obiektów częściowych, zamiany ich w pozorną całość" ${ }^{\prime 40}$. Podmiot jest w stanie uciszyć niepokój dzięki umiejętności przemieszczenia pozytywnych uczuć (miłości) do utraconej osoby na inne obiekty. Innymi słowy, idzie o „transfer miłości, zastąpienie [...] kochanej osoby innymi ludźmi lub rzeczami" ${ }^{41}$. Mechanizm ten dobrze

37 P. Coates Wajdowska wyobraźnia katastroficzna. Trauma wojenna, surrealizm i kicz, przeł. T. Misiak, w: Filmowy świat Andrzeja Wajdy, s. 99-118. Tego, że Wajda bywał - czasami niesłusznie rozczarowany własnymi filmami, najlepiej dowodzą jego - podszyte narcyzmem - słowa z okresu realizacji Wesela (1972): „Siedziałem ścierpnięty i zdrętwiały ze zgrozy, że do tego doprowadziłem swój w końcu niemały talent" (A. Wajda Kino i reszta świata, Znak, Kraków 2000, s. 100).

38 M. Klein Żałoba i jej zwiq̨zek ze stanami maniakalno-depresyjnymi, w: tejże Miłość, poczucie winy i reparacja oraz inne prace z lat 1921-1945, przeł. D. Golec, A. Czownicka, Gdańskie Wydawnictwo Psychologiczne, Gdańsk 2007, s. 356.

Kleinowska teoria relacji z obiektem oraz pojęcie „reparacji” w refleksji nad kinem pojawiły się głównie w analizach koncentrujących się na filmowych widzach: kobiecym (S. Gordon „Breaking the Waves" and the Negativity of Melanie Klein: Rethinking the Female Spectator, "Screen" 2004 No. 45 (3), s. 206-225) czy gejowskim (B. Farmer The Fabulous Sublimity of Gay Diva Worship, "Camera Obscura” 2005 No. 20 (2), s. 164-195). W kontekście estetyki sytuuje ją m.in. Davina Quinlivan w inspirującym tekście o Walcu z Baszirem (2008, reż. Ari Folman) i Przerwanych objęciach (2009, reż. Pedro Almodóvar): Film, Healing and the Body in Crisis: A Twenty-first Century Aesthetics of Hope and Reparation, "Screen” 2014 No. 55 (1), s. 103-117.

E. Kosofsky Sedgwick Czytanie paranoiczne, czytanie reparacyjne..., s. 7 .

M. Klein Miłość, poczucie winy i reparacja, w: tejże Miłość, poczucie winy i reparacja oraz inne prace z lat 1921-1945, s. 321. 
oświetla Wajdowskie kino traumy, w którym proces reparacji dokonuje się z jednej strony za sprawą uwewnętrznienia utraconych obiektów, z drugiej zaś poprzez substytuty obiektu. Jak we Wszystko na sprzedaż, filmie, po pierwsze, o Zbigniewie Cybulskim, który zginął tragicznie pod kołami pociągu w 1967 roku, po drugie, o reżyserze w kryzysie (Andrzej Łapicki) bezradnym wobec realizowanego właśnie filmu. Za realizacją tego filmu, podobnie jak i filmów z okresu Szkoły Polskiej, stało poczucie winy, co jest tym bardziej znaczące, że to właśnie ów pobudzający sublimację oraz sprzyjający kreatywności i twórczości stan jest zdaniem Klein impulsem reparacji ${ }^{42}$. Wojenne filmy z okresu Szkoły Polskiej reżyser tworzył w przeświadczeniu, że ukazane na ekranie losy powinny być częścią jego życia ${ }^{43}$.Ze względu na młody wiek nie uczestniczył czynnie w wojnie, zarazem podkreślał, że w 1942 roku skończył 16 lat i osiągnął wiek poborowy. Geneza Wszystko na sprzedaż wiąże się z kolei ze słowami Cybulskiego - „Powiedz mu [Wajdzie - przyp. S.J.], że jeszcze za mną zatęskni" - które aktor miał wypowiedzieć rok przed tragiczną śmiercią do ich wspólnego znajomego ${ }^{44}$.

W filmie tym proces żałoby dokonuje się zarówno za sprawą uwewnętrznienia utraconego, kochanego obiektu (Zbigniew Cybulski), jak i odtworzenia innych utraconych obiektów (Andrzej Wróblewski). Figury przedwcześnie zmarłych przyjaciół, w których twórczości temat śmierci był jednym z motywów wiodących, są swoistymi talizmanami umożliwiającymi reżyserowi symboliczne scalenie rozbitej tożsamości. Wróblewski i Cybulski mieli decydujący wpływ na wczesną twórczość Wajdy: ten pierwszy miał swój udział w decyzji o porzuceniu przez niego malarstwa, drugi z kolei upewnił go - dzięki sukcesowi Popiołu i diamentu - w słuszności obranej drogi45. Tadeusz Lubelski, analizując Wszystko na sprzedaż jako historię wewnętrznej metamorfozy reżysera, który - za sprawą doświadczenia samotności i kontaktu ze śmiercią - „dociera do swego mitu inicjacyjnego, związanego z sensem sztuki i zobowiązaniem artysty”, zauważa, że „dręczenie się pytaniem «kim naprawdę byli» [Wróblewski i Cybulski - przyp. S.J.] jest dla autora filmu sposobem zdobycia recepty na to, jak stać się na powrót jednym

42 Tamże, s. 330-332.

Andrzej Wajda. Moje notatki z historii, 1996, reż. Andrzej Wajda.

44 Por. A. Wajda Kino i reszta świata, s. 109.

45 Por. T. Lubelski „Mówi do nas”. Wyobrażenie Autora w filmach Andrzeja Wajdy, w: Filmowy świat Andrzeja Wajdy, s. 25. 
z nich"46. Tym samym rozbity, pokawałkowany podmiot po katastrofie zostaje scalony poprzez identyfikację z tragicznie zmarłymi przyjaciółmi. Identyfikacja jako ratunek. Mamy tu do czynienia z integracją z utraconymi obiektami, co pozwala odzyskać siebie.

Jednak Wajdowskie kino traumy przekształca się w kino nadziei nie tylko za sprawą uwewnętrznienia utraconych obiektów, lecz także dzięki wyborowi nowego obiektu. Beata, żona reżysera, w rolę której wcieliła się ówczesna żona Wajdy, Beata Tyszkiewicz, prosi go, by do niej wrócił, gdyż jest on, jak mówi, „z nim (Aktorem-Cybulskim), ze zmarłymi”. Ale to nie ona okaże się substytutem utraconego obiektu, nie na nią przemieszczone zostaną uczucia. Daniel (w tej roli Daniel Olbrychski), idący za śladami pozostawionymi przez mitycznego Aktora, jest tu pasowany na jego następcę, ale przede wszystkim na kolejny przedmiot pragnienia reżysera. „Myślisz, że nie potrafię się zakochać drugi raz?”, zapytuje Daniela reżyser. A ten odpowiada: „Może, jeśli się pan drugi raz ożenił". W rozgrywającym się na planie filmowym finale, powtarzającym szokową reakcję Elżbiety i Beaty na śmierć Aktora, widzimy Daniela, który źle się czuje w cudzej roli, roli Aktora. W pewnej chwili dostrzega stado galopujących koni i biegnie w ich stronę. Zrzuca kożuch i rozkłada ręce w geście wolności. Asystent radzi Reżyserowi, by skierował na niego kamerę, ten - choć wydaje się sceptyczny („tak, rób to dalej sam”) - nie odwraca od aktora wzroku. Spojrzenie to jest znaczące: ciało Olbrychskiego będzie odtąd funkcjonowało w filmach Wajdy jako erotyczny przedmiot, fetysz idealny, łączący w sobie falliczną siłę i „kobiecy” wdzięk. W Ziemi obiecanej nie tylko jest przedmiotem erotycznego spojrzenia kobiet (Anka, Zuckerowa, Müllerówna) i innych mężczyzn (głównie zakochanego w Borowieckim Moryca, ale także Maksa, choćby w scenie „striptizu” Polaka), lecz również kamery/reżysera ${ }^{47}$.

Reparacyjne kino Wajdy zamykały dotąd sceny pełne pesymizmu, niemocy i rozpaczy. W finale Popiołu i diamentu Maciek umiera na śmietniku w konwulsjach. Po śmierci tytułowej Lotnej Adam Pawlikowski łamie szablę, a my, widzowie, oglądamy wyblakły krajobraz po apokalipsie, pełen straszących konarów drzew. W ostatniej scenie Popiołów obojętny Napoleon przejeżdża saniami obok oślepionego Olbromskiego, a w tle majaczą okrzyki: „Niech żyje cesarz!”. Inaczej we Wszystko na sprzedaż, gdzie przepełniona młodzieńczą witalnością, radością i szczęściem finałowa scena jest, jak się zdaje, znakiem

46 Tamże, s. 24, 27.

47 Szerzej piszę o tym w innym miejscu: S. Jagielski Maskarady męskości. Pragnienie homospołeczne w polskim kinie fabularnym, Universitas, Kraków 2013, s. 265-308. 
odrodzenia ${ }^{48}$. Obraz ten - fascynujący i przerażający zarazem - daleki jest jednak od jednoznaczności. Owszem, wyzwalający, zmysłowy bieg Daniela wśród koni symbolizuje odbudowę rozbitego świata. Sam reżyser zauważył zresztą, że scena ta wyprowadza film „z mrocznej atmosfery w stronę świa$\mathrm{tła"}^{\prime \prime 9}$. W stronę energii i życia. Ale to nie wszystko. Ostatnie ujęcia ukazują bowiem w zwolnionym tempie szamoczącego się w ciasnych kadrach $\mathrm{Da}$ niela. Jakby został złapany w sieć albo tonął. Jakby ktoś chciał go pochwycić i usidlić. Niby jest w ruchu, ale tkwi w miejscu. Widzimy ciało, które - jak w efekcie stroboskopowym - rozmazuje się na tle nieba. Ciało zdeformowane, nieostre niczym na obrazach Francisa Bacona. Efekt ten celnie uchwycił sam Wajda: „On sam [Daniel - przyp. S.J.] w oczach reżysera rozpływa się, znika, nie widać go, tylko cień kogoś, kto ni to się rodzi, ni to ginie... i tak kończy się film, jak urwana w aparacie projekcyjnym taśma filmowa"50. Zniekształcone ciało mężczyzny jest, po pierwsze, projekcją samego reżysera, ucieleśnia więc, być może, jego lęki i pragnienia. Jak u Klein, która pisała, że "uczucie miłości i dążenie do reparacji rozwija się w powiązaniu z impulsami agresywnymi i pomimo ich obecności" ${ }^{51}$. Po drugie, ciało filmu, jego przestrzenna organizacja, fragmentacja, a przede wszystkim odwołanie do „urwanej taśmy filmowej” sygnalizuje znieruchomienie, niepokojący zastój, agonię (czy tylko ciała filmu?). Po trzecie wreszcie, nowy obiekt okazuje się kimś między życiem i śmiercią, przyjemnością i cierpieniem, częścią i pełnią.

48 Reparacja dokonuje się we Wszystko na sprzedaż także za sprawą samej formy. Wciąż mamy tu do czynienia z ekscesem stylistycznym, ale nie jest to już eksces Eisensteinowski. Wajda przywykły do tradycyjnej narracji - realizuje nowofalowy i autotematyczny film o strukturze luźnej, otwartej i improwizowanej. Kontrastowe połączenia kolorystyczne i „niestosowne zestawienia" obiektów nie odsyłają już do Buñuela i surrealizmu, lecz do Warhola i pop-artu. Kino Wajdy z końca lat 6o. wiedzie przez "sztukę z łachmanów": „rzeźbę z klozetowego papieru, rzeźbę ze szmat, rzeźbę wyciśniętą w plastyku" (R. Polański, A. Wajda Reżyser filmowy i świat współczesny, "Kino" 1972 nr 2, s. 35). Reżyser w czasie realizacji Wszystko na sprzedaż twierdził, że "nowego momentu” w kinie należy szukać w „podziemnych" filmach amerykańskich, które okazują się, jego zdaniem, fundamentalne dla „filozoficznej, myślowej strony pop-artu”. Toteż odnowy szukał nie tyle we francuskiej Nowej Fali, która pod koniec lat 6o. była już pieśnią przeszłości, lecz w pop-arcie. Sam zresztą powtarzał, że "sztuka z łachmanów” ma go doprowadzić do "sztuki prawdziwej" (tamże). I rzeczywiście, Wszystko na sprzedaż, Polowanie na muchy (1969), Krajobraz po bitwie (1970) oraz Piłat i inni (1971) doprowadziły go do arcydzieł z lat 70. Tamże.

M. Klein Miłość, poczucie winy i reparacja, w: tejże Miłość, poczucie winy i reparacja oraz inne prace z lat 1921-1945, s. 301. 
Tym samym jest w tym obrazie ucieleśnienie metamorfozy i wizualizacja reparacji, jest trauma i mrok, ale też nadzieja i światło.

\section{Abstract}

\section{Sebastian Jagielski}

JAGIELLONIAN UNIVERSITY (CRACOW)

Ecstatic Explosions: Wajda, Affect and Reparation

Andrzej Wajda's films are based on visual excess. His method consists of a loose stringing together of contrasting images, which brings to mind Sergei Eisenstein's notion of pathos. Both Wajda and Eisenstein conceive of affects as structures that work on the viewer through form. Jagielski sheds light on the affective structures that accompany the style of Wajda's films, which allows him to create a juncture between a new understanding of film (Eugenie Brinkema) and affective heritage (Eisenstein). At the same time he reminds us that this problem has a long tradition in film theory. Finally, Jagielski describes the genesis of Wajda's film style and its references to trauma - the trauma of war, the trauma of history, as well as Wajda's own private trauma.

\section{Keywords}

Andrzej Wajda, excess, affect, pathos, reparation, body 